\title{
GESTATIONAL TROPHOBLASTIC DISEASES: FOURTEEN YEAR EXPERIENCE OF OUR CLINIC
}

\section{Mertihan KURDOGLU, Zehra KURDOGLU, Zehra KUCUKAYDIN, Hanim Güler SAHIN, Mansur KAMACI}

Department of Gynecology and Obstetric, Faculty of Medicine, Yuzuncu Yil University, Van, Turkey

\begin{abstract}
SUMMARY
Objective: To evaluate the patients followed and treated with a diagnosis of gestational trophoblastic disease in our clinic retrospectively.

Design: The files of the patients followed and treated in our clinic between 1996 and 2010 with a diagnosis of gestational trophoblastic disease were examined.

Setting: Yuzuncu YIl University, Faculty of Medicine, Department of Obstetrics and Gynecology, Van. Patients: The 147 patients with satisfactory information in their files within 173 patients treated and followed in our clinic between 1996 and 2010 with a diagnosis of gestational trophoblastic disease.

Interventions: No intervention to the patients.

Main outcome measures: Demographic and obstetric parameters, blood group,obstetric history in the previous pregnancy, contraceptive method, gestational week and complaints on admission, hystological type, stage, treatment and complications of gestational trophoblastic disease and presence of associated clinical problems. Results: In our clinic, 18.324 deliveries occured and 173 cases had a diagnosis of gestational trophoblastic disease between 1996 and 2010. Out of 147 patients, 72 (49\%), 61 (41.5\%), 3 (2\%), 7 (4.8\%) and 1 (0.7\%) had diagnoses of complete mole, partial mole, invasive mole, choriocarcinoma and placental site trophoblastic tumor, respectively. In 3 patients (2\%), subtype could not be determined. Mean age was $31.45 \pm 10.29$ years and the most common complaint was vaginal bleeding (77.6\%). As the primary therapy, suction curettage with oxytocin infusion or hysterectomy was appplied to 140 and 7 patients, respectively. A single agent chemotherapy was performed to 26 patients while a multiagent chemotherapy was given to 6 patients. All patients were followed up by serial serum $\beta$ hCG measurements.

Conclusions: The incidence of gestational trophoblastic disease in our clinic was calculated as 8.1 per 1000 deliveries and socio-economic and educational status of majority of the patients were low. Lowering the high birth rate in our region may contribute to decrease of disease incidence.
\end{abstract}

Key words: gestational trophoblastic disease, hydatidiform mole, incidence

Journal of Turkish Society of Obstetrics and Gynecology, (J Turk Soc Obstet Gynecol), 2011; Vol: 8 Issue: 2 Pages: 134- 9

\section{ÖZET}

\section{GESTASYONEL TROFOBLASTIK HASTALIKLAR: KLİNí̆IMIZİN 14 YILLIK DENEYIMI}

Amaç: Kliniğimizde gestasyonel trofoblastik hastalı tanıslyla takip ve tedavileri yaplan hastaların retrospektif değerlendirilmesi.

Planlama: Kliniğimizde 1996-2010 yılları arasında gestasyonel trofoblastik hastalık tanısı alarak takip ve tedavisi

Address for Correspondence: Zehra Kurdoğlu. Yüzüncü Yı1 Üniversitesi Tıp Fakültesi, Kadın Hastalıkları ve Doğum Anabilim Dalı, Van, Turkey Phone: +90(505) 3102316

e-mail: zehrakurdoglu@hotmail.com

Received: 20 July 2010, revised: 20 July 2010, accepted: 08 December 2010, online publication: 14 March 2011 
yapılmış olan hastaların dosyaları incelenmiştir.

Ortam: Yüzüncü Yll Üniversitesi Tıp Fakültesi, Kadın Hastalıklarl ve Doğum Kliniği, Van.

Hastalar: Kliniğimizde 1996-2010 yılları arasında gestasyonel trofoblastik tanısı konulan, takip ve tedavileri yapılan 173 hastadan dosya bilgilerine ulaşılabilen147 hasta.

Girişim: Herhangi bir girişim uygulanmamıştır.

Değerlendirme parametreleri: Demografik ve obstetrik parametreler, kan grubu, önceki gebeliğine ait obstetrik öykü, korunma yöntemi, başvuru esnasındaki gebelik haftası ve şikayetler, gestasyonel trofoblastik hastaliğın histolojik tipi, evresi, uygulanan tedaviler ve komplikasyonlar ile eşlik eden klinik problem varlı̆̆l.

Sonuç: Kliniğimizde 1996-2010 yılları arasında 18234 doğum gerçekleşmiş ve 173 olguya gestasyonel trofoblastik hastalık tanısı konulmuștur. Yüz kırk yedi hastanın 72'de (\% 49) komplet mol, 61'de (\% 41.5) parsiyel mol, 3 'de (\% 2) invaziv mol, 7'de (\% 4.8) koryokarsinom, 1'de (\% 0.7) plasental site trofoblastik tümör tespit edilmiştir. Üç hastada (\% 2) subtip belirlenememiştir. Ortalama yaş $31.45 \pm 10.29$ yıl olup en sık başvuru şikayeti vaginal kanama (\% 77.6) idi. Primer tedavi olarak 140 hastaya oksitosin infüzyonu ile birlikte vakum küretaj, 7 hastaya ise histerektomi uygulanmıştır. Yirmi altı hastaya tek ajan kemoterapi, 6 hastaya da multiajan kemoterapi protokolleri uygulanmıştır. Tüm hastalar, $\beta$ hCG takibine alınmıştır.

Yorum: Kliniğimizde görülen gestasyonel trofoblastik hastalık insidansı 8.1/1000 doğum olarak hesaplanmış, hastalarımızın çoğunluğunun eğitim ve sosyoekonomik düzeyinin düşük olduğu tespit edilmiştir. Bölgemizdeki yüksek gravida ve parite oranlarının azaltılması bu hastalı̆̆ın insidansının düşmesine katkıda bulunabilir.

Anahtar kelimeler: gestasyonel trofoblastik hastalı, hidatiform mol, insidans

Türk Jinekoloji ve Obstetrik Derneği Dergisi, (J Turk Soc Obstet Gynecol), 2011; Cilt: 8 Sayl: 2 Sayfa: 134- 9

\section{INTRODUCTION}

Gestational trophoblastic diseases belong to a group of diseases that occur because of the abnormal proliferation of trophoblasts which are present in placenta. They are histologically classified as complete and partial hydatidiform mole, invasive mole, choriocarcinoma and placental site trophoblastic tumour(1).

Incidence of the disease which is the only gynecologic malignancy with androgenic origin varies according to the geographical regions ${ }^{(2)}$. While it is rarer in North American and European countries, its incidence has been determined as 0.3-16.0/1000 pregnancies and 1.0-24.5/1000 births in Turkey(3). Socio-economical status, blood group, menarche age, maternal age, parity, previous molar pregnancy history, genetic factors, malnutrition, parasites and infections are among the risk factors ${ }^{(4)}$.

In this study, it was aimed to evaluate the patients followed and treated between the dates of 1.1.1996 and 13.4.2010 with a diagnosis of gestational trophoblastic disease in Yuzuncu Yil University, Faculty of Medicine, Department of Obstetrics and Gynecology retrospectively and to determine the incidence of gestational trophoblastic diseases in Van region.

\section{MATERIAL AND METHODS}

Of the 173 patients followed and treated with a diagnosis of gestational trophoblastic disease between the dates January 1996 and April 2010 in Yuzuncu Yil University Faculty of Medicine, Department of Obstetrics and Gynecology clinic, 147 patients with satisfactory information in their files were enrolled in the study. Patients' age, profession, education level, socioeconomical status, blood group, menarche age, gravidity, parity, abortus history in the previous pregnancy, contraceptive method, complaints on admission, histological type of gestational trophoblastic disease, molar pregnancy history, term birth history in previous pregnancy, gestational week, presence of hyperemesis and hyperthyroidism, presence of preeclampsia and eclampsia, stage, treatment and complications of gestational trophoblastic disease were recorded.

SPSS 17.0 statistics program was used in evaluating the data. Differences between age groups, gravidity and parity numbers in terms of gestational trophoblastic diseases frequency were evaluated using $\mathrm{z}$ test.

First of all, pelvic and physical examination, serum $\beta$ hCG, complete blood count, renal, hepatic and thyroid 
function tests were done and chest X-rays were performed for all the patients. Uterus and adnexial areas were evaluated using an Esaote Picus Pro ultrasound device. The presence of metastasis was investigated by performing additional computed cerebral, abdominal and lung tomography examinations in the cases with abnormal findings.

For the purpose of final diagnosis and treatment, initially vacuum curettage was performed on patients under the operating room conditions. Hysterectomy was conducted on the suitable patients by taking the patient's age and parity into consideration. Patients were monitored for serum $\beta$-hCG after vacuum curettage. They were followed weekly until their serum $\beta$-hCG values were under $5 \mathrm{mIU} / \mathrm{ml}$ for 3 times consecutively and then they were followed monthly for 1 year. During the follow up, the patients whose $\beta$-hCG values don't remit; on the contrary increase or enter plateau phase even though 12 weeks were elapsed after the curettage were regarded to have a persistent gestational trophoblastic neoplasia. Chemotherapy was given to patients for whom the diagnosis of choriocarcinoma was established pathologically after the evacuation or metastasis was determined at the beginning or during the follow-up or whose serum $\beta$-hCG values increased during the follow-up. Single agent chemotherapy was used for the treatment of non-metastatic (FIGO Stage I), low risk (good prognosis) metastatic (FIGO Stage II-III / WHO Score <8) gestational trophoblastic neoplasias. Multi agent combined chemotherapies were used for ones which don't respond to this treatment or with high risk (poor prognosis) metastatic (FIGO Stage IV / WHO Score >8) gestational trophoblastic neoplasias. In single agent chemotherapy; one of the methotrexate rescue (methotrexate on the 1, 3, 5, 7 . days $1 \mathrm{mg} / \mathrm{kg} /$ day, folinic acid on the $2,4,6,8$. days $0.1 \mathrm{mg} / \mathrm{kg} /$ day), methotrexate $20-25 \mathrm{mg}$ /day 5 days, $50 \mathrm{mg} / \mathrm{m}^{2} /$ day, once a week protocols was performed. The course wasn't repeated if there was a rapid decrease in $\beta$-hCG values after the first treatment and as long as this decrease continued. But a second course of chemotherapy was recommended for the patients whose $\beta$-hCG values keep steady or start increasing. Combined chemotherapy was performed on the patients who didn't respond to this treatment or high risk patients. EMA-CO (Etoposide, Methotrexate, Actinomycin-D, Vincristine, Cyclophosphamide) or EP/EMA (Etoposide, Cisplatin/ Etoposide, Methotrexate,
Actinomycin-D) was used as combined chemotherapy protocol. EMA-CO protocol was performed this way:

\section{EMA (Course 1)}

Day 1; Etoposide $100 \mathrm{mg} / \mathrm{m}^{2}$ in $200 \mathrm{ml}$ saline over 30 minutes; methotrexate $100 \mathrm{mg} / \mathrm{m}^{2}$ intravenous; actinomycin-D $0.5 \mathrm{mg}$ intravenous push

Day 2; Etoposide $100 \mathrm{mg} / \mathrm{m}^{2}$ in $200 \mathrm{ml}$ saline over 30 minutes; actinomycin-D $0.5 \mathrm{mg}$ intravenous push; folinic acid $15 \mathrm{mg}$ orally or intramuscularly twice daily for 4 doses, begining 24 hours later than the start of methotrexate. Five days of interval without medicine is taken before the second course.

CO (Course 2) Day 1; Cyclophosphamide $600 \mathrm{mg} / \mathrm{m} 2$ infusion over 20 minutes; vincristine (Oncovin) 1 $\mathrm{mg} / \mathrm{m} 2$ intravenous push (maximum $2 \mathrm{mg}$ ). Six days following this were without medicine.

EP/EMA protocol was performed as follows;

EP; Day 1; Etoposide $100 \mathrm{mg} / \mathrm{m}^{2}$ in $250 \mathrm{ml}$ saline over 30 minutes; cisplatine $75 \mathrm{mg} / \mathrm{m}^{2}$, intravenous over 12 hours.

EMA; Day 1; Etoposide $100 \mathrm{mg} / \mathrm{m}^{2}$ in $200 \mathrm{ml}$ saline over 30 minutes; methotrexate $300 \mathrm{mg} / \mathrm{m}^{2}$ intravenous over 12 hours; actinomycin-D $0.5 \mathrm{mg}$ intravenous push. Weekly $\beta$-hCG follow-ups were continued after the chemotherapy. Chemotherapy was carried on until $\beta$-hCG level was normal for 3 times consecutively. Oral contraceptive was recommended as the contraceptive method for all the patients followed.

\section{RESULTS}

Between the dates January 1996 and April 2010, 18234 pregnant women gave birth in Yuzuncu Yil University, Faculty of Medicine, Department of Obstetrics and Gynecology clinic, and gestational trophoblastic disease incidence was calculated as $8.1 / 1000$ births. Of the 147 patients with satisfactory information on their files, complete mole was determined in 72 (49\%), partial mole in $61(41.5 \%)$, invasive mole in $3(2 \%)$, choriocarcinoma in $7(4.8 \%)$ and placental site trophoblastic tumour in $1(0.7 \%)$. Subtype couldn't be determined in 2 patients $(2 \%)$.

Primary admission complaint of the cases was vaginal bleeding $(77.6 \%)$ followed by menstrual delay (10.2\%), nausea and vomiting $(2 \%)$ and passage of vesicles $(0.7 \%)$. 
Mean age of the patients was $31.45 \pm 10.29$ (1756) (Table I). Menarche ages were varying between 11 and 15 , and were calculated as a mean of $12.68 \pm 0.83$. Seventy one percent of the patients were housewives, $77.6 \%$ were illiterate and income of $66 \%$ was low.

Table I: Age distribution of the patients.

\begin{tabular}{lrr}
\hline Age (year) & Number $(\mathbf{n}=)$ & Percentage $(\mathbf{\%})$ \\
\hline $15-19$ & 16 & 10.88 \\
$20-24$ & 29 & 19.73 \\
$25-29$ & 30 & 20.41 \\
$30-34$ & 19 & 12.93 \\
$35-39$ & 10 & 6.80 \\
$40-44$ & 20 & 13.61 \\
$45-49$ & 16 & 10.88 \\
$50-54$ & 6 & 4.08 \\
$55-59$ & 1 & 0.68 \\
Total & $\mathbf{1 4 7}$ & $\mathbf{1 0 0}$ \\
\hline
\end{tabular}

While 22 cases $(15 \%)$ were primigravid, gravidity number of 40 cases $(27.2 \%)$ changed between 5 and 9 , and gravidity of 9 cases $(6.1 \%)$ was more than 15 (Table II). It was determined that 27 of the patients were nulliparous $(18.4 \%)$ and parity of 3 patients $(2.1 \%)$ was determined as more than 15 (Table III).

Table II: Gravidity characteristics of the patients.

\begin{tabular}{lrr}
\hline Gravidity & Number $(\mathbf{n}=)$ & Percentage $(\mathbf{\%})$ \\
\hline 1 & 22 & 15 \\
2 & 21 & 14.3 \\
3 & 16 & 10.9 \\
4 & 13 & 8.8 \\
$5-9$ & 40 & 27.2 \\
$10-14$ & 26 & 17.7 \\
$15-18$ & 9 & 6.1 \\
Total & $\mathbf{1 4 7}$ & $\mathbf{1 0 0}$ \\
\hline
\end{tabular}

Table III: Parity characteristics of the patients.

\begin{tabular}{lrr}
\hline Parity & Number $(\mathbf{n}=)$ & Percentage (\%) \\
\hline 0 & 27 & 18.4 \\
1 & 24 & 16.3 \\
2 & 14 & 9.5 \\
3 & 11 & 7.5 \\
4 & 11 & 7.5 \\
$5-9$ & 37 & 25.1 \\
$10-14$ & 20 & 13.6 \\
$15-17$ & 3 & 2.1 \\
Total & $\mathbf{1 4 7}$ & $\mathbf{1 0 0}$ \\
\hline
\end{tabular}

When blood groups were examined; it was monitored that 69 patients (46.9\%) were A, 25 (17\%) were B, 17 (11.6\%) were $\mathrm{AB}$ and 36 (24.5\%) were 0 type. When contraceptive methods were examined; it was monitored that 3 patients ( $2 \%$ ) used IUD (intra uterine device), $1(0.7 \%)$ used oral contraceptive, 7 (4.8\%) used coitus interruptus method, $1(0.7 \%)$ used condoms whereas 113 patients $(76.9 \%)$ didn't use any contraceptive methods. Contraception information of 22 patients (15\%) couldn't be collected.

In 47 of the patients (32\%) history of spontaneous abortion; in 6 (4.1\%) molar pregnancy; in 94 (63.9\%) term birth history in the previous pregnancy; in 76 (51.7\%) hyperthyroidism; in 22 (15\%) hyperemesis; in $5(3.4 \%)$ preeclampsia and in $2(1.4 \%)$ eclampsia was determined (Table IV).

Table IV: Characteristics of the previous pregnancies and additional clinical problems of the patients accompanying the present trophoblastic disease.

\begin{tabular}{|c|c|c|c|}
\hline & $\begin{array}{l}\text { Present } \\
\text { (n) }(\%)\end{array}$ & $\begin{array}{l}\text { Non-present } \\
\text { (n) }(\%)\end{array}$ & $\begin{array}{l}\text { Unknown } \\
\text { (n) }(\%)\end{array}$ \\
\hline \multicolumn{4}{|l|}{ History of } \\
\hline spontaneous abortion & $47(\% 32)$ & $100(\% 68)$ & - \\
\hline D \& C history & $15(\% 10.2)$ & $130(\% 88.4)$ & $2\left(\begin{array}{ll}\% & 1.4\end{array}\right)$ \\
\hline \multicolumn{4}{|l|}{ History of previous } \\
\hline molar pregnancy & $6(\% 4.1)$ & $141(\% 95.9)$ & - \\
\hline \multicolumn{4}{|l|}{ Term birth history } \\
\hline \multicolumn{4}{|l|}{ in the previous } \\
\hline pregnancy & $94(\%$ 63.9) & $38(\% 25.9)$ & $15(\% 10.2)$ \\
\hline Hyperthyroidism & $76(\% 51.7)$ & $71(\% 48.3)$ & - \\
\hline Hyperemesis & $22(\% 15)$ & $100(\% 68)$ & $25\left(\begin{array}{ll}\% & 17\end{array}\right)$ \\
\hline Preeclampsia & $5(\% 3.4)$ & $142(\% 96.6)$ & - \\
\hline Eclampsia & $2(\% 1.4)$ & $145(\% 98.6)$ & - \\
\hline
\end{tabular}

Table V: Distribution of the patients by FIGO staging.

\begin{tabular}{lrr}
\hline Stage & Number $(\mathbf{n}=)$ & Percentage $\mathbf{( \% )}$ \\
\hline Stage I & 137 & 93.1 \\
Stage II & - & - \\
Stage III & 6 & 4.1 \\
Stage IV & 2 & 1.4 \\
Unknown & 2 & 1.4 \\
Total & $\mathbf{1 4 7}$ & $\mathbf{1 0 0}$ \\
\hline
\end{tabular}

Mean gestational week was $13.49 \pm 3.49$ at the time of diagnosis. As a treatment; vacuum curettage under general anesthesia was performed on 130 patients $(88.4 \%)$, hysterectomy after vacuum curettage on 10 patients $(6.8 \%)$ and hysterectomy on 7 patients (4.8 $\%$ ) who have completed their fertility. While uterine perforation developed in 1 patient during vacuum curettage, 1 patient died of acute respiratory failure due to trophoblastic embolization. Besides, it was required to perform preoperative beta blocker treatment 
in $39(26.5 \%)$ of the cases with hyperthyroidism. Distribution of the patients according to the staging of International Federation of Gynecology and Obstetrics (FIGO) was demonstrated in Table V. Methotrexate was given to 3 followed patients once a week using the $50 \mathrm{mg} / \mathrm{m}^{2}$ protocol. Four courses and 2 courses of methotrexate were given to 2 and 1 patients respectively. Methotrexate rescue (methotrexate on the 1, 3, 5, 7 . days $1 \mathrm{mg} / \mathrm{kg} /$ day, folinic acid on the $2,4,6,8$. days $0.1 \mathrm{mg} / \mathrm{kg} /$ day) protocol was performed on nineteen patients. Methotrexate at the dose of 20-25 mg/day over 5 days was given to 1 patient for 2 courses, and on 3 patients for 1 course. Multi agent combined chemotherapy was given to 6 patients. Of these patients, results of three were reported as choriocarcinoma, one as molar, one as invasive molar and one as placental site trophoblastic tumour. Two courses of EMA-CO were performed on one of the patients with the diagnosis of choriocarcinoma when serum $\beta$-hCG values kept steady after 1 course of methotrexate treatment. Other patient with the diagnosis of choriocarcinoma was treated with 9 courses of EMA-CO and 5 courses of EP/EMA protocols when serum $\beta$-hCG values increased. Another patient whose pathology result was choriocarcinoma was treated with 7 courses of methotrexate-rescue and because no remission developed during the 8 weeks follow-up, 4 courses of EMA-CO protocol were performed. Five courses of EMA-CO protocol were performed on a stage IV patient with invasive mole and liver metastases, and 9 courses of EMA-CO protocol was performed on a stage III case with the diagnosis of placental site trophoblastic tumour. Four courses of EMA-CO protocol were performed on a patient who had the diagnosis of partial mole and was treated with 3 courses of methotrexate-rescue protocol after the serum $\beta$-hCG values kept steady.

\section{DISCUSSION}

Gestational trophoblastic diseases contain a group of benign and malign diseases pathogenesis of which isn't clarified exactly ${ }^{(5)}$. Different incidences have been reported as a result of epidemiological studies all around the world. It has been shown in the society based studies that molar pregnancy incidence in South East Asian countries are 2-3 times more than that of the European countries ${ }^{(6)}$. While hydatidiform mole incidence is $11.5 / 1000$ births in Indonesia, it is less than $1 / 1000$ in America ${ }^{(4)}$. Mole pregnancy incidence in Japan was determined as 2.5/1000 live births in 1974 and started to decrease dating from 1991, and determined as $1.65 / 1000$ live births in $2000^{(7)}$. In Turkey; Gul et al. reported the gestational trophoblastic disease incidence as $12.9 / 1000$ births in a study conducted in 1997, Cetin et al. reported as 6.6/1000 births, Yalcin et al. reported the hydatidiform mole incidence in the countryside as $0.83 / 1000$ births, Gul et al. reported the gestational trophoblastic disease incidence as 24.5 in 1000 births in a study conducted in $2000^{(8-10)}$. In our study, gestational trophoblastic disease incidence was determined as 8.1 in a thousand births. Lower incidence result compared to a study carried on in our clinic again between the years 1995 and 1998 may be due to increase of the births in our clinic throughout the years and conducting of patient follow-ups partially outside the clinic with the increase in the health service providing institutions.

Regarding the patient age groups, 16 patients $(10.88 \%)$ under the age of 20,88 patients $(59.86 \%)$ within the range of 20-39 and 43 patients (29.25\%) at the age of 40 and over were present. Compared to the other age groups, gestational trophoblastic diseases within the age group in reproduction age was determined as significantly more $(\mathrm{p}=0.001)$. In the literature, it has been stated that frequency risk of the disease under the age of 20 increases 1.5 times and 5.2 times above the age of $40^{(11)}$.

While most frequent admission complaint is vaginal bleeding, symptoms of passage of vesicles, hyperemesis, hyperthyroidism and preeclampsia may accompany. Apart from these, abnormal findings such as trophoblastic embolism, adult respiratory distress syndrome (ARDS), hypovolemic shock, anemia, heart failure may appear(12). In our study, it was monitored that patients attended most frequently with the complaint of vaginal bleeding (77.6\%) followed by menstrual delay $(10.2 \%)$, pain $(9.5 \%)$, nausea and vomiting $(2 \%)$, passage of vesicles $(0.7 \%)$. Besides, hyperthyroidism was determined in $51.7 \%$, preeclampsia in $3.4 \%$ and eclampsia in $1.4 \%$ of the patients. One patient died of acute respiratory failure due to trophoblastic embolization.

It has been stated in the literature that maternal blood group A was more frequently seen in molar 
pregnancies $^{(13)}$. In this research it was also monitored that most of the patients (46.9\%) have the blood group A

When gravidities of the patients were compared; gestational trophoblastic disease frequency in the women with the gravidity number 5 and above was determined as statistically significantly higher than the primigravids $(p=0.001)$. Similarly, more gestational trophoblastic diseases were determined in grand multipars with the parity of 5 and over compared to nullipars $(\mathrm{p}=0.001)$.

First option in the diagnosis and treatment of molar pregnancy is vacuum curettage. Hysterectomy may also be considered as one of the treatment methods for the patients who completed fertility. All the patients should be followed with serial hCG measurements after the vacuum curettage ${ }^{(1,12,14)}$. Vacuum curettage with oxytocin infusion was performed under general anesthesia on 140 patients in the study. Perforation developed in one of them during the curettage procedure. They were followed weekly until negative serum $\beta$-hCG values were obtained for 3 times consecutively and then their hCG values were followed monthly for 1 year. Oral contraceptives were recommended to the patients for 12 months as stated in the literature after their serum $\beta$-hCG values were negative. By this way, both contraception and repression of LH that can cross react with and hCG was provided (15)

Main treatment method for gestational trophoblastic neoplasias is chemotherapy and some protocols with single and multi agents were determined. Chemotherapy wasn't performed on 115 patients whereas single agent chemotherapy was performed on 26 patients and multi agent EMA-CO and EP/EMA combined chemotherapy were performed on 6 patients.

In conclusion, majority of our patients have a low socio-economical status and education. Incidence in our clinic is higher than the incidences determined in some studies in the literature. Decreasing of the high gravidity and parity ratios in our region may contribute to the decrease in the incidence of this disease.

\section{KAYNAKLAR}

1. DiSaia PJ, Creasman WT. Gestational Trophoblastic Neoplasia. In: DiSaia PJ, CreasmanWT, eds. Clinical Gynecologic Oncology. St Louis: Mosby-Yer Book Inc, 1997: 180- 201.

2. Yalçın ÖT. Gestasyonel Trofoblastik Neoplaziler ve Yönetimi. TJOD Uzmanlık Sonrası Eğitim Dergisi 2004; 8: 189- 96.

3. Ozalp SS, Yalçin OT, Tanır HM. Hydatidiform mole in Turkey from 1932 to 2000. Int J Gynecol Obstet 2001; 73: 257- 8 .

4. Bracken MB, Brinton LA, Hayashi K. Epidemiology of hydatidiform mole and choriocarcinoma. Epidemiol Rev 1984; 6: $52-75$.

5. Palmer JR, Driscoll SG, Rosenberg L, Berkowitz RS, Lurain JR, Soper J. Oral contraceptive use and risk of gestational trophoblastic tumors. J Natl Cancer Inst 1999; 91: 635- 40.

6. Hayashi K, Bracken MB, Freeman DH Jr, Hellenbrand K. Hydatidiform mole in the United States (1970-1977): a statistical and theoretical analysis. Am J Epidemiol 1982; 115: 67- 77.

7. Matsui H, Iitsuka Y, Yamazawa K, Tanaka N, Seki K, Sekiya $\mathrm{S}$. Changes in the incidence of molar pregnancies. A populationbased study in Chiba Prefecture and Japan between 1974 and 2000. Hum. Reprod 2003; 18: 172- 5.

8. Gül T, Yilmaztürk A, Erden AC. A review of trophoblastic diseases at the medical school of Dicle university. Eur J Obstet Gynecol Reprod Biol 1997; 74: 37- 40.

9. Çetin M, Balta Ö, Duran B, Güvenal T, Yanar O. Kliniğimize Başvuran Mol Gebelik Olgularının Retrospektif İncelenmesi. C. Ü. Tıp Fakültesi Dergisi 2004; 26: 18- 22.

10. Gül A, Çelebi H. Yüzüncü Yıl Üniversitesi Tıp Fakültesi Kadın Doğum Kliniğindeki Trofoblastik Hastalıkların Değerlendirilmesi. T Klin J Gynecol Obst 2000; 10: 192- 5.

11. Lurain JR. Pharmacotherapy of gestational trophoblastic disease. Expert Opin Pharmacother 2003; 4: 2005- 17.

12. Kendall A, Gillmore R: Chemotherapy for trophoblastic disease: current standarts. Curr Opin Obstet Gynecol 2002; 14: 33- 8.

13. Bagshwe KD, Dent J, Webb J: Hydatiform mole in United Kingdom 1973-1983. Lancet 1986; 2: 673- 7.

14. Berkowitz RS, Goldstein DP, DuBeshter B, Bernstein MR. Management of complete molar pregnancy. J Reprod Med 1987; 32: 634- 9 .

15. Gaffield ME, Kapp N, Curtis KM. Combined oral contraceptive and intrauterine device use among women with gestational trophoblastic disease. Contraception 2009; 80: 363- 71. 